\title{
A Study on Offering Chinese Culture Course for Non-English Major Students in China
}

\author{
Hang Zou \\ School of Foreign Languages, Jiangsu University, Zhenjiang, Jiangsu Province, China
}

\begin{abstract}
In an era when English is widespreadly used as the uncontested lingua franca, learning English is becoming an increasingly focal point in China. Realizing the fact that students' cross-cultural communication skills hold such an important place in their language learning process, the college English language curriculum has been modified to better enhance students' cross-cultural communication ability and indeed certain innovations can be identified. However, problems still exist especially for non-English major students. They are exposed to curriculum which is solely concerned with the understanding of 'Anglo' cultures and the shortage of Chinese culture in college English teaching can obstruct students' communication ability. The study explores the necessities of offering Chinese culture course in English language for non-native English major students. On the basis of the focused interview, the study focuses on students' previous learning experience and demonstrates their expectations for this course. Combining students' responses and drawing on evidence from students' expectations, the course is designed in detail and evaluated in terms of what is worthwhile and effective in enhancing students' cross-cultural communication ability. It is argued that, such a course will make it possible for students to become successful cross-cultural communicators and eventually improve their English proficiency.
\end{abstract}

Index Terms - curriculum, motivation, culture, English-language teaching

\section{INTRODUCTION}

Foreign language education is currently experiencing rapid and significant change. The need for students in China to acquire language proficiency in language other than Chinese is more critical than ever, especially in light of the challenges that economic globalization and social mobility pose to students in the 21st century (Spring and Madeline, 2012). Education is an activity which not only aims at cultivating students with knowledge but preparing people for life, for living. Today, the aim of preparation needs to take into account the context of an accelerating globalization in which the learning of English is becoming an increasingly focal point for China's higher education system. It is commonly observed that modern technology has turned our world into a small village. (He and Miller, 2011, p. 428). Under the situation of globalization, improving students' cross-cultural communication skills becomes particularly important because lots of chances are available for learners in China to communicate with people around the world. When talking about the cross-cultural communication ability, the relationship between language and culture can not be overlooked. A well-known fact is that culture and language are closely interrelated. "Language is the principal means whereby we conduct our social lines. When it is used in contexts of communication, it is bound up with culture in multiple and complex way" (Kramsch, 1998, p. 3). That is to say, when we learn a foreign language, understanding that culture is of great importance. Just as Byram (1994) states, "cultural learning has to be take place as an integral part of language learning, and vice versa" (p. 5). Culture should be understood as the 'active process of meaning making' (Street, 1993, p. 25), and seen as the act of "doing" rather than just "being", namely, as dynamic and fluid rather than static and predefined (Alsagoff, 2010). That is to say, how to more efficiently incorporate culture learning in foreign language classes should be attached great importance. Then, the question regarding which culture should be taught arises: the native culture the learner possesses based on past experiences, or the culture of the foreign language, or both of them? Considering English teaching in China, western culture teaching is indeed a part of the curriculum. However, the question of the role of Chinese culture in the curriculum is overlooked by educators and, as a result, lots of problems have arisen. For example, the potential threat of learning foreign languages to students' national identity, the unsatisfactory ability of expressing things relating to Chinese culture when communicating with English speakers and so on. Just as Rao (1996) claims, "Chinese students remain at a loss when they meet English speakers. Students of English can neither understand what the English speakers say, nor can they express themselves in English" (p. 458). Based on the above problems, my research seeks to identity the necessities of offering Chinese culture course in English language for non-English major students. In the first part, through the focused interview, students' previous experience relating to conducting cross-cultural communication and their expectations for this course are illustrated. Then, the course is described in detail and evaluated in terms of its effective effects in enhancing students' communication ability. The third part focuses on the significance of offering such a course for students followed by the conclusion part.

\section{THE STUdENTs' EXPERIENCE AND EXPECTATIONS}


The focused interview was conducted to illustrate students' English language learning experience and the problems which they met during the process of conducting cross-cultural communication. A total of 50 informants among which 15 participants are engineering major students, 20 are Chinese major students and 15 participants major in business were interviewed individually. Each student was required to answer several questions and the qualitative data was then gathered to provide some useful information for the design of the course because learners' opinions count a lot in the teaching process. Below are some typical comments by participants which reflect what they said about their experience of learning English and their self evaluation of proficiency in English language when conducting cross-cultural communication.

Interviewer: Do you think English language learning is a successful experience for you?

Interviewee: When I was in high school, learning English was not a difficult thing for me because every time I could get relatively high scores in the examination. After entering college, I find that most times we need to learn by ourselves and if we can pass CET4 (College English Test Band 4) and CET6 (College English Test Band 6), we almost achieve the ultimate goal. However, I still find it is hard for me to express my ideas in English in class sometimes. (Jin, female)

Interviewer: How much do you know about cross-cultural communication ability? Do you have some chances to meet English speakers and communicate with them? Are you a good communicator?

Interviewee: Our English teacher mentions a little about it when offering college English courses. I have some basic knowledge about such kind of ability and I know it is very important. Ever semester, we have several classes taught by foreign teachers so we have chances to chat with them. Generally speaking, I think I am a good communicator and I really like to communicate with others in English. (Yang, male)

Interviewer: Are you good at expressing western topics? Are you troubled by expressing topics concerning Chinese ones?

Interviewee: Our English teacher often introduces something relating to western culture to us before the detailed discussion of the text. Our textbook contains some articles on western culture and we can know a lot from it. However, we rarely have the chance to learn something about our native culture. Actually, I do not know how to translate "si da fa ming" in English. (Qiang, Male)

Interviewer: Do you think it is necessary to offer Chinese culture course in English language for you?

Interviewee: Yes, it is crucial. I remember once I met a foreigner when I paid a visit to the West Lake. The foreigner was so interested in the story of the White Snake and he expected me to tell him the story. However, I found it is so hard for me to describe the whole story in English because I do not know how to translate some Chinese words into English. I felt very frustrated. (Lin, female)

\section{OFFERING ChINESE CUlture COURSE IN JiANGSU UNIVERSITY}

\section{A. Background}

Realising the significant role of English and considering English as the preferred language of world trade and commerce, science and technology and international relations, it is no wonder that since the mid 1960s, English has been taught in universities in China. This has been given political approval: "The study of English is regarded as necessary for acquiring technological expertise and for fostering international trade by Chinese Communist Party" (Adamson and Morris, 1997, p. 3). Since English has become a compulsory course, the English language curriculum attracts people's attention because it directly relates to language teaching and student learning. The college English curriculum has been modified to meet the learners' needs and innovations in the curriculum can be found such as the changing focus from writing and reading to speaking and listening, the emphasis on enhancing students' learning strategies and capacity for intercultural communication and so on. However, we still find that there are some problems relating to the teaching content which have negative effects on learners learning process. One of them is the shortage of Chinese native culture teaching in the process of college English language teaching. It is well known that language classes should incorporate the teaching of culture as part of their content, and just as the linguistic model, cultural content of English courses in the Expanding Circles traditionally focused on that of Americans and Britons (Matsuda and Friedrich, 2011). For example, both the teaching material and the teaching pedagogy are imported from western countries. What's more, most of the recommended articles relating to English learning are written by English-speakers. As a result, students' learning motivation is low and their intercultural communication ability is not satisfactory. The reason is that we live in a certain culture just like a fish lives in the water. Once we come to a quite different culture, we just like a fish out of water $(\mathrm{Lu}, 2012)$. When students are exposed to the language in the text book which they do not share, they may feel that they are not part of the culture they are learning about and tend to feel a barrier even reject the whole process. In 2010, Xiao Longfu and some other teachers made an investigation into the ability of non-English major students to communicate in English about Chinese culture. The investigation illustrates that though Chinese people know a lot of Chinese and Chinese culture, many people still fail to express the native culture in English language. Chinese cultural aphasia does exist. Considering the fact that the spread of English has broadened the definition of 'English-speaking culture,' the cultural content of an EIL class also needs to expand (Matsuda and Friedrich, 2011). In order to solve the problem, the Chinese culture course in English language in Jiangsu university is planned to be offered for one year. The first semester exposes students to an introduction to Chinese culture. It aims at 
equipping students with basic knowledge of Chinese traditional culture and more importantly, cultivating their ability of expressing and translating topics relating to Chinese culture in English language. The second semester focuses on the comparison between Chinese culture and western culture so as to make students understand the cultural differences, express those differences in English language and explore the reasons behind those differences. The second semester is also for practice, which is in fact, a very major aspect of providing chances for enhancing abilities of expressing, evaluating and spreading Chinese culture.

\section{B. Aims of the Course}

The course aims to enhance students' ability to express Chinese culture in English language. It also aims at bringing positive learning experiences to students by encouraging them to conduct cross-cultural communication and making them aware of the fact that cross-cultural communication is a two-way orientation. What's more, offering Chinese culture course is also the need of spreading the Chinese culture. The reason is that only when we have a good command of English language and Chinese culture in the language of English, can we spread the native culture when communicating with foreign guests. It is of great importance for Chinese people to be able to express topics on Chinese culture so that people outside of the country can understand China from their perspectives and know more about Chinese history, legend, civilization and so on. Furthermore, it also aims to provide a channel for students to improve their English language proficiency by offering them the opportunity to listen to lectures on Chinese culture, read selected works, and interact with each other in workshops, which will at last develop students' critical thinking ability.

\section{Teaching Pattern of the Course}

It has become common knowledge that teaching methods have great effects on students' learning outcomes. As Richards and Rodgers (2001) claim, "If language learning is to be improved, it will come about through changes and improvements in teaching methodology" (p. 15). The teacher should make great efforts to enhance students' ability of expression, translation ability and critical thinking ability. In order to achieve this goal, the student-centered teaching strategy should be advocated and the communicative language teaching methodology as well as task-based instruction should be adopted. The course is conducted through lectures on introducing some basic knowledge along with workshops which aims at providing opportunities for students to learn from each other and to know what their classmates have done. Students in each class are divided into four to five groups for workshops and the workshop is held every month lasting 60 minutes. Students in each group communicate with each other on some given topics, make comments and ask questions so as to share their opinions. At the workshop, teachers act as the facilitators who provide help when necessary and encourage students to express their own viewpoints freely. After class, students are required to do some tasks relating to the course. While processing the requested tasks, students have opportunities to read more, communicate with people and think dependently. For example, students are required to find articles on Chinese culture which is full of Chinese characteristic and translate articles after class. At the workshop, students make comments on their classmates' work and revise the translation version through discussion. Such kind of teaching method can arouse students' interest and motivate them to learn. As for the way of assessment, it can be comprehensive such as tests, writing essay, oral translation, presentation and so on, which is inclined to assess students ability to express Chinese culture, evaluate the cultural differences between Chinese culture and western culture, translate articles including words, expressions, idioms relating to Chinese cultural connotations.

\section{DESCRIPTION}

\section{A. Lectures}

McDermott (1993) claims that "teaching by telling is an ineffective mode of instruction for most students. Students must be intellectually active to develop a functional understanding" (p. 297). In order to achieve the best learning outcomes, the two-way interactive teaching method which stresses upon self-learning and encourages teacher-student interactions should be adopted. It is the teaching approach that provides time and questions for students to think and discuss. In that way, it is easier for teachers to cultivate a supportive classroom atmosphere to promote interactions and promote learners' intellectual engagement and learning motivation in class. Specific speaking, teachers combine discussion teaching method with question teaching method through various in class activities such as group discussion and students' giving lectures so as to arouse students' enthusiasm for the course and improve their communicative skills to a great extent. When giving lectures, teachers can put forward some heated-discussion topics relating to native culture and discuss them with students. Besides, by asking questions or letting students present their puzzled questions for the whole class discussion, teachers aims at promoting students' participation in the learning process, which is beneficial to their performance. In each lecture, students are provided with 3-5 concept questions and sufficient time to think about and discuss these questions. For example, the lecturer presents some pictures relating to the four great inventions of ancient China and then poses some questions to the students from easy to difficult, from describing to comparing them with inventions of other countries. The students are first asked to think about these questions individually, then to discuss with their neighbours, and finally to discuss them with the whole class. What's more, the questions chosen by teachers are mostly context-rich ones which are related to students' everyday life and their background knowledge. 


\section{B. Selection of the Dominant Instructional Model}

It is commonly believed that the dominant instructional model(s) of the course should be selected according to the aim of the course and the needs of learners. If an English program was situated in a community where English is used exclusively or extensively and its goal was to assist newcomers get adjusted to the new community, the variety used locally is probably the most appropriate model (Matsuda and Friedrich, 2011). For this course, the selection of an instructional variety should be made locally and individually. Various contextual factors such as learner goals, learner's language proficiency, teacher's background and the material availability should be taken into consideration. For most students taking this course, the variety used locally is probably the most appropriate model.

\section{Selection of Teaching Materials}

It is acknowledged that the selection of teaching materials is an integral part of curriculum planning because it influences the learner's learning outcome to a great extent. "Coursebooks provide teachers and learners with a range of professionally developed materials within tried and tested syllabus structures', allowing teachers to spend their valuable time more on facilitating learning than materials production" (Bell and Gower, 1998, p. 116). Actually, there are varieties of coursebooks on teaching Chinese culture such as "Aspects of Chinese Culture" published by Tsinghua university press, "An Introduction to Chinese Culture" published by Congqing university press, "Chinese Culture: A Course Book" published by University of Science and Technology of China press and so on. By collecting all the insightful and meaningful articles from more than 20 books, teachers edit the teaching material based on the students' interest, which focuses on different aspects of Chinese culture such as a brief history of China, Chinese characters and language, calligraphy and painting customs and festivals, Chinese religions, architecture and gardens, traditional Chinese medicine, Chinese philosophy and so on. For the second semester, the teaching material contains articles mainly about the analyses of cultural differences between Chinese culture and western culture and the causes behind them. Based on the topics on the coursebook for the first semester, the second semester textbook provides information on corresponding cultural things in western countries so as to make students compare the cultural differences and search for the causes.

\section{Workshops}

Besides lectures, the workshop is held every month lasting 60 minutes which provides more chances for students to share their experience as well as their findings and helps to improve students' language proficiency. "The main purpose of the workshop is to learn how to do something better or to understand something better. Participants adopt the role of learners. Resource persons have high expertise and behave as instructors. The workshop may include the learning of skills and thus involve much practice" (This, 1979, p. 51). Therefore, such kind of meeting of people who cooperate with each other in groups dealing with problems by themselves allows considerable practices and communications. In the workshop, teachers put forward some problems or assign some tasks relating to the course content, which requires students to fulfill some tasks such as translating articles, evaluating some different cultural phenomena, presenting their group work findings, writing some papers and so on. It is believed that "The workshop can be considered a unique instructional format for continuing education programs. Although it shares some characteristics with other formats, it has features that make it unique and uniquely suited to achieving a particular type of learning outcome" (Thomas and Sork, 1984, p. 10). On the whole, students hold positive attitudes towards the workshops and they are looking forward such kind of teaching format. One student replied in the interview:

Actually there are few opportunities for us to attend the workshops. I think it is an effective and interesting way for us to learn more and communicate with our classmates. I hope I can improve my expression ability and English language proficiency through it and I will try my best to take part in it (Fei, female).

\section{SignificAnces of OfFering Chinese Culture Course for Non-English Major Students in China}

The purpose of using English is not solely to learn from others, as we may have believed in the past. Our goal now is to establish and maintain an equal, mutually respectful relationship with others, which requires the ability to perceive and analyze the familiar with an outsider's perspective (Matsuda and Friedrich, 2011). Therefore in addition to global culture and the cultures of future interlocutors, what is equally important for EIL users is the knowledge of the students' own culture and the ability to explain it in such a way that outsiders can understand it. For non-English major students, they have fewer English classes then English major students while still get the chance to use English for communication purpose as English majors. By offering Chinese culture course for them, students can become more motivated to study and their cross-cultural communication ability can be greatly enhanced.

In the first place, offering Chinese culture course in English language for non-English major students has the effect of enhancing students' learning motivation and improving students' learning outcomes. "For the learners who have deeper understanding and appreciation of the target language as well as deeper understanding and appreciation of native culture have a 'productive orientation' in language learning" (Fromm 1948, cited in Gao and Cheng and Zhao and Zhou 2005, p. 40); they are more motivated by self-actualization needs" (Maslow 1957, cited in Gao and Cheng and Zhao and Zhou 2005, p. 40). It is believed that when identifying with one's own culture, students can learn foreign language easier because they see themselves as a speaker of that language and are more willing to use the language to communicate, 
which helps enhance their learning motivation. The research of Gardner and Lambert and of Acton and Walker de Felix determined that integrative motivation (the intention of becoming a part of the target culture as well as speaking the target language) resulted in more effective language learning than did instrumental motivation (the intention of learning the language to serve a purpose, such as getting a job (cited in Valdes, 1986, p. 2). When learning the course, students will feel familiar with the teaching content and they don't need to express themselves about something strange to their temperament or alien to their thought, which will arouse their interest.

Secondly, offering Chinese culture course for non-English major students can enhance their cross-cultural ability. According to the interview, most students though have some knowledge of Chinese culture, they lack of the ability to express them when communicating with foreigners. The fact that cross-cultural communication is a two-way orientation suggests that during the process of communication, just talking about western culture will not arouse the interest of foreigners and can not meet the need of foreigners who are curious about Chinese culture. Only by introducing Chinese culture to foreigners and discussing the cultural difference with them, can we conduct the successful and meaningful cross-cultural communication. What's more, two non-native English speakers are able to understand each other better when conducting communication even if they do not talk within the framework of, for instance, British culture (Suzuki, 1975). We need to admit the fact that English, influenced by one's own native language and own culture and his own personality, can be used with confidence.

Thirdly, offering Chinese culture course for non-English major students can help to maintain their national identity and it corresponds with Chinese foreign language policy. Kirkpatrick (2002) claims that "speakers of a new variety of English will want to preserve their identity, and the reflection of their pragmatic and cultural norms in the local variety of English is an important way of doing this" (p. 215). When learning the course, students are more aware of their own culture and they have opportunities to gain a deeper understanding of national culture, which helps them to maintain their national identity. English has a sort of psycho-cultural advantage for the speakers because they do not need to throw their own identity away (Suzuki, 1975). Just as Dunnett, Dubin and Lezberg have point out, "the EFL teacher, while introducing foreign students to some aspects of American culture, must also encourage students to maintain their own cultural identity. To achieve this, the teacher must talk about cultural relativism as well as the universality of certain components shared by different cultures" (cited in Valdes, 1986, p. 158). Besides, adding Chinese culture in the English curriculum also corresponds with Chinese foreign language policy. Chang (2006) claims that "The prominence that English has in language policy is due to the enormous prestige of its instrumental value. The dominance of English is such an inevitable reality that language policy must come to terms with it. The most important thing is that its dominance must be properly managed so as to produce maximally favorable outcomes for China" (p. 516). Adding Chinese culture in college English language curriculum can therefore ensure better learning outcomes, help to maintain national identity, and reserve and promote national culture, which can benefit the whole country.

\section{CONCLUSION}

This paper has discussed the Chinese culture course in English language for non-English major students in Jiangsu University, and in light of the evaluation offers considerable changes as they would be implemented in Chinese universities. The role of national culture in the English language curriculum should be taken into consideration because it is as impossible to escape from one's native culture as it is to get out of one's own skin. This paper has sought to explore and address problems relating to college students English leaning, conducted form the aspect of culture and its significance for learning. I have proposed that it may be particularly important and effective that students read foreignproduced texts about their own country or locality. We should be aware that English curriculum design should meet the needs of students according to real-life situations and in the Chinese context, for learners need an English language teaching curriculum that teaches them about the cultures of people they are most likely to be using English with, and more importantly, they need to figure out how to compare, relate and present their own culture to others.

\section{ACKNOWLEDGMENT}

This work was supported in part by the National Science Foundation of China under Grant 61102054 and in part by the Research Foundation for Advanced Talents, Jiangsu University, under Grant 10JDG109.

\section{REFERENCES}

[1] Adamson B. and Morris P. (1997). The English Curriculum in the People's Republic of China. Comparative Education Review 41.1, 3-26.

[2] Alsagoff L. (2010). English in Singapore: culture, capital and identity in linguistic variation. World Englishes 29.3, 336-348.

[3] Bell J.\& Gower R. (1998). Writing course materials for the world: a great compromise. In B. Tomlinson (eds), Materials Development in Language Teaching. Cambridge, UK: Cambridge University Press, 116-129.

[4] Boas F. (1986). Language and thought. In Valdes J. M (eds.), Culture Bound: Bridging the Cultural Gap in Language Teaching. Cambridge: Press Syndicate of University of Cambridge, 1-5.

[5] Byram C., Morgan C.,\& colleagues. (1994). Teaching-and-learning Language-and-culture. Clevedon, UK: Multilingual Matters Limited.

[6] Chang J. Y. (2006). Globalization and English in Chinese higher education. World Englishes 25.3/4, 513-525. 
[7] Dunnett S. C., Dubin F. \& Lezberg A. (1986). English language teaching from an intercultural perspective. In J. M Valdes (eds), Culture bound: Bridging the cultural gap in language teaching. Cambridge: Press Syndicate of University of Cambridge, 148161.

[8] Gao Y., Cheng Y., Zhao Y. \& Zhou Y. (2005). Self-identity changes and English learning among Chinese undergraduates. World Englishes 24.1, 39-51.

[9] He D. and Miller L. (2011). English teacher preference: the case of China's non-English-major students. World Englishes 30.3, 428-443.

[10] Kirkpatrick A. (2002). ASEAN and Asian cultures and models: Implications for ELT curriculum and for teacher selection. In A. Kirkpatrick (eds), Englishes in Asia: Communication, identity, power and education, Melbourne, Australia: Language Australia, 213-224.

[11] Kramsch C. (1998). Language and culture. Oxford, UK: Oxford University Press.

[12] Lu W. and Wan J. (2012). On treating intercultural communication anxiety of international students in China. World Journal of Education 2.1, 55-61.

[13] Matsuda A. and Friedrich P. (2011). English as an international language: A curriculum blueprint. World Englishes 30.3, $332-$ 344.

[14] McDermott L. (1993). "How we teach and how students learn- A mismatch?". Am. J. Phys 61.4, 295-298.

[15] Rao Z. H. (1996). Reconciling Communicative Approaches to the Teaching of English with Traditional Chinese Methods. Research in the Teaching of English 30.4, 458-471.

[16] Richard J. C. and Rodgers T. S. (2nd edn.) (2001). Approaches and methods in language teaching. London: Cambridge University Press.

[17] Spring, Madeline K. (2012). Language for specific purposes curriculum in the context of Chinese-Language flagship programs. The Modern Language Journal 96.1, 140-157.

[18] Street and Brain. (1993). Culture is a verb: anthropological aspects of language and cultural process. In D. Graddol, L. Thompson \& M. Byram (eds), Language and Culture, Clevedon, UK: Multilingual Matters, 23-43.

[19] Suzuki T. (ed.) (1975). Tozasareta Gengo: Nihongo no Sekai (The Closed Language: the World of the Japanese Language). Tokyo: Shincho Sensho.

[20] Thomas J. and Sork. (2006). The Workshop as a Unique Instructional Format. New Directions for Adult and Continuing Education 1984.22, 3-10.

[21] This L. E. (2nd ed.) (1979). Tlu Small Meeting Planner. Houston: Gulf.

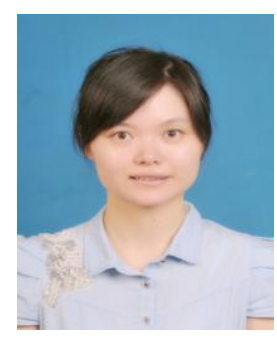

Hang Zou was born in Zhenjiang, Jiangsu Province, China. She received the M. A. degree in TESOL international from Monash University, Melbourne, Australia in 2009. She is currently a lecturer in the School of Foreign Languages, Jiangsu University, Zhenjiang, Jiangsu Province, China. Her research fields include applied linguistics, second language acquisition and English language teaching methodology. 